\title{
Global research trends of Middle East respiratory syndrome coronavirus: a bibliometric analysis
}

\author{
Sa'ed H. Zyoud ${ }^{1,2}$
}

\begin{abstract}
Background: Middle East respiratory syndrome coronavirus (MERS-CoV) is a virus that causes severe viral pneumonia in humans, known to have a high mortality rate and a similarity in clinical symptoms with severe acute respiratory syndrome coronavirus. It was first isolated in Kingdom of Saudi Arabia (KSA) in 2012 and after that, MERS-CoV exhibited outbreaks in several regions of the world. This study aimed to assess the characteristics of publications involving MERS-CoV at global level by using a bibliometric analysis.

Methods: Scopus database was searched on March 4, 2016 for MERS-CoV publications published between 2012 and 2015. It was performed on the same day in order to avoid the possible bias came from update on the database because the metrics are changing over time. All publication types were considered; however publications as errata were excluded. Analysis parameters include year of publication, publication type, patterns of international collaboration, research institutions, journals, impact factor, $h$-index, language, and times cited.
\end{abstract}

Results: A total of 883 MERS-CoV research publications were published across the world. The MERS-CoV-associated publications were originated from 92 countries/territories, indicating the international spread of MERS-CoV research. The USA was the largest contributor, with 319 articles published over 4 years, followed by KSA (113 articles). The total number of citations for these publications has already achieved 8,015, with an average of 9.01 citations per each publication. The $h$-index for MERS-CoV-associated publications was 48. The USA also have the highest $h$-index (32), followed by KSA (26) and UK (22). Netherland produced the greatest proportion of publications with international research collaboration (72.7 \%) followed by the UK (71 \%) and Germany (69.1\%) out of the total number of publications for each country.

Conclusions: There is a rapid increase in research activities related to MERS-CoV from 2012 to 2015. This study demonstrates that the MERS-CoV related literature has grown to be more extensive and global over the past 4 years. The bulk of publications in the field of MERS-CoV research are published by high-income countries such as the USA. Furthermore, the USA, the UK and KSA may have higher quality of articles according to the value of $h$-index.

Keywords: Bibliometric, Scopus, Coronavirus, Middle East respiratory syndrome coronavirus, MERS-CoV

\footnotetext{
Correspondence: saedzyoud@yahoo.com; saedzyoud@najah.edu

'Division of Clinical and Community Pharmacy, Department of Pharmacy,

Faculty of Medicine and Health Sciences, An-Najah National University,

Nablus 44839, Palestine

${ }^{2}$ Poison Control and Drug Information Center (PCDIC), Faculty of Medicine

and Health Sciences, An-Najah National University, Nablus 44839, Palestine
} 


\section{Background}

Middle East respiratory syndrome coronavirus (MERS$\mathrm{CoV}$ ) is a virus that causes severe viral pneumonia in humans, known as having a high mortality rate and having a similarity in clinical symptoms with severe acute respiratory syndrome coronavirus [1-3]. It was first happened in Jordan in April, 2012 [4], and then the virus was isolated from a patients in Kingdom of Saudi Arabia (KSA) [5-7]. After that, MERS-CoV exhibited outbreaks in several regions of the world [8-12]. Although MERS-CoV is thought to be a zoonosis, probably camels act as a direct source of human MERS-CoV infection [13, 14], most cases are now due to human-to-human transmission $[9$, 11, 12, 15-17]. The virus was firstly nominated Human Coronavirus Erasmus Medical Center/2012 (HCoV-EMC/ 2012) [5], but after global consensus it was renamed MERS-CoV [18].

In order to evaluate its current impact on global scientific research production, a bibliometric analysis was performed using available information indexed at most common journals-indexing databases, such as Scopus. Bibliometric analysis examines the progress of any topic and offers a comprehensive assessment of scientific research trends. In recent years, bibliometric analysis has been extensively performed to assess scientific activities in many fields, including infectious diseases such as Mayaro virus fever [19], Zika virus [20], Ebola virus disease [21, 22], yellow fever disease [23], dengue [24], Malaria [25], leishmaniasis [26, 27], influenza [28], and John Cunningham virus [29]. To the best of knowledge of the author, there has been no bibliometric study about MERS-CoV research in the English literature. This study aimed to assess the characteristics and quality of articles involving MERS-CoV at global level. The study approach is employed to assess MERS-CoV related research characteristics such as countries, journals, research institutions, and citation habits.

\section{Methods}

Publications used in this analysis were extracted from the Scopus database developed by Elsevier in the Netherlands. Scopus is a relatively large database compared to PubMed and Web of Science [30] which contains information for publications published in more than 21,500 titles of which 20,000 are peer-reviewed journals from more than 5,000 international publishers [31]. Selected publications included "Middle East respiratory syndrome coronavirus" or "MERS-CoV" or "Human Coronavirus Erasmus Medical Center/2012" or "HCoV-EMC/2012" as a part of its title, abstract, or keyword from 2012 till the date of December 31, 2015 All of these terms are used in one query. Publications as errata or publications which their scope was not related to MERS-CoV, and publications from 2016 were excluded from the study. Research indicators for the assessment of MERS-CoV research output were determined according to the methods used previously in similar bibliometric studies [32-37]. Analysis parameters include date (year) of publication, publication type, patterns of international collaboration, research institutions, journals, impact factor (IF), $h$-index, language, and times cited. International collaborations were considered when the paper affiliation contained different countries.

To measure the impact and/or productivity of the research published in the field of MERS-CoV, $h$-index and IF were used as bibliometric indicators for this evaluation. The $h$-index was introduced in literature in 2005 by Hirsch for the assessment of individual academic attainment [38]. The $h$-index can more truthfully represent the author's or country's achievement; a higher $h$ index shows that the publication $\mathrm{s}$ larger influential power. The IF of the journals as reported in Journal Citation Reports ${ }^{\circ}$ (JCR) 2014 was used [39]. Only the ten top-ranked journals were considered and they were shown in descending order from 1st to 10th using the standard competition ranking (SCR), with the highest absolute number of publications ranked 1 , as obtained on the day of data collection (March 4, 2016). Data collection and analysis were performed on the same day in order to avoid the possible bias came from update on the database because the metrics are changing over time. Parameters with the same number of publications were given the same rank number.

\section{Statistical analysis}

The analysis was performed using descriptive statistics in Microsoft Excel 2007, and SPSS statistical software (SPSS for Windows, version 15, SPSS Inc Chicago, IL, USA). The analysis involved the calculation of relative frequencies, percentages, sum, and average.

\section{Results}

A total of 883 MERS-CoV-associated publications were retrieved in the study search. Nine publications were published in 2012, 155 in 2013, 318 in 2014, and 401 in 2015. Around sixty percent of total share was published as original articles, $13.3 \%$ as reviews, $9.5 \%$ as editorial materials, $7.5 \%$ as letters, and the remaining being note, erratum, and conference Paper. Among these articles, 829 (93.9 \%) were written in English, 18 (2.04 \%) were in Korean, 12 (1.4 \%) were in Chinese, 10 (1.1\%) were in German, and the remainder of articles were in a variety of other languages such as French, Czech, Dutch, Greek, Polish, and Hungarian.

The MERS-CoV-associated publications were originated from 92 countries/territories, indicating the international spread of MERS-CoV research. Table 1 shows the 10 countries with the highest number of publications included in the $h$-indices. Out of 883 publications, the USA was the 
Table 1 Top ten countries/territories with scientific production on MERS-CoV research at Scopus (up to December 31, 2015)

\begin{tabular}{lllll}
\hline SCR & Countries/territories & $\begin{array}{l}\text { Total number of publications } \\
\text { for the whole period (\%) }\end{array}$ & h-index & $\begin{array}{l}\text { Number (\%) of publications } \\
\text { with international collaboration }\end{array}$ \\
\hline 1st & United States & $319(36.1)$ & 32 & $168(52.7)$ \\
2nd & Saudi Arabia & $113(12.8)$ & 26 & $76(67.3)$ \\
3rd & China & $103(11.7)$ & 19 & $63(61.2)$ \\
4 th & United Kingdom & $93(10.5)$ & 22 & $66(71.0)$ \\
5 th & Hong Kong & $71(8.0)$ & 18 & $47(66.2)$ \\
6 th & Germany & $68(7.7)$ & 21 & $47(69.1)$ \\
7 th & Netherlands & $55(6.2)$ & 21 & $40(72.7)$ \\
8 th & South Korea & $39(4.4)$ & 4 & $4(10.3)$ \\
9 th & France & $37(4.2)$ & 10 & $17(45.9)$ \\
10 th & Australia & $27(3.1)$ & 6 & $13(48.1)$ \\
\hline
\end{tabular}

SCR standard competition ranking

largest contributor, with 319 (36.1\%) articles published over 4 years; this was followed by KSA (113, $12.8 \%)$, China (103, $11.7 \%)$, and the UK (93, $10.5 \%)$. The total number of citations for these publications has already achieved 8,015, with an average of 9.01 citations per each publication. The $h$-index for MERS-CoV-associated publications was 48. The USA also have the highest $h$-index (32), followed by KSA (26) and the UK (22). Netherland produced the greatest proportion of publications with international research collaboration $(72.7 \%)$ followed by the UK (71 \%) and Germany (69.1\%) out of the total number of publications for each country (Table 1).

The MERS-CoV-associated publications were published in 384 different journals, but most frequently in these journals: Journal of Virology (46), Emerging Infectious Diseases (43), Eurosurveillance (36), and The Lancet Infectious

Table 2 The 10 most published journals

\begin{tabular}{llll}
\hline $\mathrm{SCR}^{\mathrm{a}}$ & Journal & Frequency (\%) & $\mathrm{IF}^{\mathrm{b}}$ \\
\hline 1st & Journal of Virology & $46(5.2)$ & 4.439 \\
2nd & Emerging Infectious Diseases & $43(4.9)$ & 6.751 \\
3rd & Eurosurveillance & $36(4.1)$ & 5.722 \\
4th & The Lancet Infectious Diseases & $35(4.0)$ & 22.433 \\
5th & MBio & $34(3.9)$ & 6.786 \\
6th & The lancet & $24(2.7)$ & 45.217 \\
7th & International Journal of & $20(2.3)$ & 1.859 \\
& Infectious Diseases & & \\
8th & Virus Research & $17(1.9)$ & 2.324 \\
9th & Journal of the Korean & $15(1.7)$ & $\mathrm{NA}$ \\
& Medical Association & & \\
9th & Journal of Infectious Diseases & $15(1.7)$ & 5.997 \\
\hline
\end{tabular}

SCR standard competition ranking, NA not available, IF impact factor ${ }^{a}$ Equal journals have the same ranking number, and then a gap is left in the ranking numbers

${ }^{\mathrm{b}}$ The impact factor was reported according to the journal citation reports (JCR) 2014
Diseases (35); (Table 2). The IF for journals including top 10 cited MERS-CoV publications ranged from 1.859 to 45.217.

Table 3 shows the top-cited publications published in the field of MERS-CoV [2, 5, 6, 18, 40-46]. The 10 most frequently cited articles have been cited more than 137 times from their initial publication year until March 4, 2016. The most frequently cited article (645 citations) was published by Zaki et al. in 2012 in the New England Journal of Medicine [5], followed by Assiri et al. [40] which was published in the New England Journal of Medicine in 2013. Majority of the top cited papers were published in journals with high IF (IF > 10).

The contribution of the 10 most productive institutes in MERS-CoV research from 2012 to 2015 is shown in Table 4. Among the top 10 institutes, 4 institutes are from the USA, 2 from KSA; and one from Hong Kong, Netherland, UK, China and Germany respectively. The University of Hong Kong had the maximum contribution in terms of the total volume of publications with 68 articles, followed by the Ministry of Health Saudi Arabia in KSA (63 articles) and Erasmus University Medical Center in Netherland (47 articles).

\section{Discussion}

The current study showed a rapid increase in research activities related to MERS-CoV in the past 4 years. The USA and KSA were the most productive countries. These results are not surprising because the USA has played an important role in fostering international cooperation on MERS-CoV research and control due to the potential risk that this represents globally. Another possible explanation for this is that the USA is the most prolific country for scientific research in general in previous bibliometric studies [19, 32-36]. It seems possible that these results are due to its size and economic strength. The ten most prolific countries that were involved in MERS-CoV research contains new nations 
Table 3 The top 10 cited publications

\begin{tabular}{|c|c|c|c|c|c|c|}
\hline$S C R^{a}$ & Authors & Title & $\begin{array}{l}\text { Year of } \\
\text { publication }\end{array}$ & Source title & Cited by & $\mathrm{IF}^{\mathrm{b}}$ \\
\hline$\overline{1 s t}$ & Zaki et al [5] & $\begin{array}{l}\text { Isolation of a novel coronavirus from a man } \\
\text { with pneumonia in Saudi Arabia }\end{array}$ & 2012 & $\begin{array}{l}\text { New England } \\
\text { Journal of } \\
\text { Medicine }\end{array}$ & 645 & 55.873 \\
\hline 2nd & Assiri et al [40] & $\begin{array}{l}\text { Hospital outbreak of middle east respiratory } \\
\text { syndrome coronavirus }\end{array}$ & 2013 & $\begin{array}{l}\text { New England } \\
\text { Journal of } \\
\text { Medicine }\end{array}$ & 256 & 55.873 \\
\hline $3 \mathrm{rd}$ & van Boheemen et al [45] & $\begin{array}{l}\text { Genomic characterization of a newly discovered } \\
\text { coronavirus associated with acute respiratory } \\
\text { distress syndrome in humans }\end{array}$ & 2012 & MBio & 217 & 6.786 \\
\hline 4th & Raj et al [46] & $\begin{array}{l}\text { Dipeptidyl peptidase } 4 \text { is a functional receptor } \\
\text { for the emerging human coronavirus-EMC }\end{array}$ & 2012 & Nature & 216 & 41.456 \\
\hline 5 th & Reusken et al [41] & $\begin{array}{l}\text { Middle East respiratory syndrome coronavirus } \\
\text { neutralising serum antibodies in dromedary camels: } \\
\text { A comparative serological study }\end{array}$ & 2013 & $\begin{array}{l}\text { The Lancet } \\
\text { Infectious } \\
\text { Diseases }\end{array}$ & 190 & 22.433 \\
\hline 6th & de Groot et al [18] & $\begin{array}{l}\text { Middle east respiratory syndrome coronavirus (MERS-CoV): } \\
\text { Announcement of the coronavirus study group }\end{array}$ & 2013 & $\begin{array}{l}\text { Journal of } \\
\text { Virology }\end{array}$ & 172 & 4.439 \\
\hline 7th & Assiri et al [2] & $\begin{array}{l}\text { Epidemiological, demographic, and clinical characteristics } \\
\text { of } 47 \text { cases of Middle East respiratory syndrome } \\
\text { coronavirus disease from Saudi Arabia: } \\
\text { A descriptive study }\end{array}$ & 2013 & $\begin{array}{l}\text { The Lancet } \\
\text { Infectious } \\
\text { Diseases }\end{array}$ & 150 & 22.433 \\
\hline 8th & Bermingham et al [6] & $\begin{array}{l}\text { Severe respiratory illness caused by a novel coronavirus, } \\
\text { in a patient transferred to the United Kingdom from the } \\
\text { Middle East, September } 2012\end{array}$ & 2012 & Eurosurveillance & 148 & 5.722 \\
\hline 9th & Guery et al [42] & $\begin{array}{l}\text { Clinical features and viral diagnosis of two cases of } \\
\text { infection with Middle East Respiratory Syndrome } \\
\text { coronavirus: A report of nosocomial transmission }\end{array}$ & 2013 & The Lancet & 139 & 45.217 \\
\hline 10th & Memish et al [43] & $\begin{array}{l}\text { Middle East respiratory syndrome coronavirus in } \\
\text { Bats, Saudi Arabia }\end{array}$ & 2013 & $\begin{array}{l}\text { Emerging } \\
\text { Infectious } \\
\text { Diseases }\end{array}$ & 137 & 6.751 \\
\hline 10th & Memish et al [44] & $\begin{array}{l}\text { Family cluster of middle east respiratory syndrome } \\
\text { coronavirus infections }\end{array}$ & 2013 & $\begin{array}{l}\text { New England } \\
\text { Journal of } \\
\text { Medicine }\end{array}$ & 137 & 55.873 \\
\hline
\end{tabular}

SCR, Standard competition ranking; NA, Not available; IF, Impact factor

${ }^{a}$ Equal articles have the same ranking number, and then a gap is left in the ranking numbers

b The impact factor was reported according to the journal citation reports (JCR) 2014

different from the familiar global ranking [47]. Through the current study, KSA leadership in MERS-CoV global research $(12.8 \%$ of the total) clearly stands up, most likely due to the fact that it was in this country where the virus originally isolated [5] and several outbreaks have been reported in this country [10, 15, 48-51]. Other countries as those located in the Asia-Pacific such as China, and South Korea have also increased their scientific MERS-CoV research output in the last year owing their new outbreaks $[8,52-56]$.

In the current study, the most commonly language used in MERS-CoV research is English. Additionally, it is because English is now used extensively and is considered one of the most widespread language in the world [57], and the majority of journals indexed in Scopus are published in English.

The findings of this study recognize the publications associated with the most important developments in the field of MERS-CoV. This bibliometric analysis reveals that the most cited article in MERS-CoV is the 2012 paper by by Zaki et al [5], in New England Journal of Medicine. This article reported the first isolated MERS-CoV in June 2012 from a Saudi male aged 60 years [5]. The second most cited article was written in 2013 by Assiri et al [40]. The authors reported a total of 23 cases related to MERS-CoV infection in the eastern region of KSA. Furthermore, the 2 most highly cited articles were published in a relatively high-IF journal (New England Journal of Medicine), which has an IF of 55.873. Some previous study showed that the IF of the journal was the strongest marker for citations [58-60]. Findings of this study verify the close relationship between IF and citations, and that the most cited articles are usually published in journals that top the IF list, which also helps keep the high IF of these journals [60]. However, the $h$-index was launched in 2005 [38] which have been used to quantify of quality and impact of the scientific research output of a researcher, countries, institutions, and journals. The $h$-index was used in the current 
Table 4 The top 10 highly productive and influential institutions in research on MERS-CoV field

\begin{tabular}{lll}
\hline$S^{2} R^{a}$ & Institution, country & No. of publications (\%) \\
\hline 1st & The University of Hong Kong, Hong Kong & $68(7.7)$ \\
2nd & Ministry of Health Saudi Arabia, KSA & $63(7.1)$ \\
3rd & Erasmus University Medical Center, Netherland & $47(5.3)$ \\
4th & Universitat Bonn, Germany & $37(4.2)$ \\
5th & University College London, UK & $36(4.1)$ \\
6th & Centers for Disease Control and Prevention, USA & $30(3.4)$ \\
7th & The University of North Carolina at Chapel Hill, USA & $28(3.2)$ \\
8th & Fudan University Shanghai Medical College, China & $27(3.1)$ \\
8th & Alfaisal University, KSA & $27(3.1)$ \\
10th & New York Blood Center, USA & $26(2.9)$
\end{tabular}

$S C R$ standard competition ranking, KSA Kingdom of Saudi Arabia

${ }^{a}$ Equal institutions have the same ranking number, and then a gap is left in the ranking numbers

study for the top 10 countries. Of the top 10 countries, 5 had an $h$-index of 20 or more.

The large impact on scientific research output in reference to MERS-CoV research replicates its global influence as a potentially harmful disease. The most interesting finding of this study was that the total number of publications with the international collaboration for each country are a bit greater than that found in earlier bibliometric reports in different fields [33, 34, 36]. While these earlier bibliometric studies have described the importance of global collaboration, which considered as the most effective strategy to increase citation rates [36, 61-63]. Moreover, the global map of scientific collaboration networks and production lets researchers to contribute for implementation of new strategy for controlling MERS-CoV outbreaks to reduce morbidity and mortality related with such outbreaks [10, 40, 50]. Furthermore, collaborative research clearly demonstrates the prioritization in searches for a appropriate vaccine as well as effective medications for treatment of MERS-CoV [64, 65].

The most important limitation lies in the fact that the Scopus database was used to search for MERS-CoV. So publications indexed in none Scopus-cited journals were not studied. Another possible limitation to this study is the use of absolute number of citations in ranking the articles, instead of rankings based on average number of citations per year. Furthermore, the number of research output in 2015 may be rising because Scopus is still open for new journals issues from this year.

\section{Conclusions}

Based on the Scopus database, the characteristics of the MERS-CoV research output from 2012 to 2015 are investigated by means of bibliometric methods. There is a rapid increase in research activities related to MERSCoV from 2012 to 2015. This study demonstrates that the MERS-CoV related literature has grown to be more extensive and global over the past 4 years. The bulk of publications in the field of MERS-CoV research are published by high-income countries such as the USA. Furthermore, the USA, the UK and KSA may have higher quality of articles according to the value of $h$-index. These findings show the value of bibliometric method to illustrate global research trends of MERS-CoV. Thus, this study provides a helpful reference for medical virologists and epidemiologists, policy decision makers, academics, and MERS-CoV researchers. As MERS-CoV can be considered a recent emerged disease, and a new research topic, the study results characterize a 'snapshot' of this field at an early stage in its development.

\section{Abbreviations}

HCoV-EMC/2012, Human Coronavirus Erasmus Medical Center/2012; IF, impact factor; IRB, institutional review board; KSA, Kingdom of Saudi Arabia; MERS-CoV, Middle East respiratory syndrome coronavirus; SCR, standard competition ranking.

\section{Funding sources}

No funding was received for writing this study.

\section{Availability of data and materials}

Not applicable.

\section{Authors' contributions}

SZ conceptualized, designed the methodology, and implemented the study, and did the analysis and write-up. Then read, and approved the final manuscript.

\section{Competing interests}

The author declares that he has no competing interests.

\section{Consent for publication}

Not applicable.

Ethics approval and consent to participate

As a bibliometric analysis, as there were no patients involved in this study, there was no need for institutional review board (IRB) approval and it was exempted. 
Received: 19 March 2016 Accepted: 27 May 2016

Published online: 07 June 2016

\section{References}

1. Arabi YM, Arifi AA, Balkhy HH, Najm H, Aldawood AS, Ghabashi A, Hawa H, Alothman A, Khaldi A, Al Raiy B. Clinical course and outcomes of critically ill patients with Middle East respiratory syndrome coronavirus infection. Ann Intern Med. 2014;160(6):389-97.

2. Assiri A, Al-Tawfiq JA, Al-Rabeeah AA, Al-Rabiah FA, Al-Hajiar S, Al-Barrak A, Flemban H, Al-Nassir WN, Balkhy HH, Al-Hakeem RF, et al. Epidemiological, demographic, and clinical characteristics of 47 cases of Middle East respiratory syndrome coronavirus disease from Saudi Arabia: a descriptive study. Lancet Infect Dis. 2013;13(9):752-61.

3. Lau SK, Chan JF. Coronaviruses: emerging and re-emerging pathogens in humans and animals. Virol J. 2015;12:209.

4. Hijawi B, Abdallat M, Sayaydeh A, Alqasrawi S, Haddadin A, Jaarour N, Alsheikh S, Alsanouri T. Novel coronavirus infections in Jordan, April 2012: epidemiological findings from a retrospective investigation. East Mediterr Health J. 2013;19:S12-8.

5. Zaki AM, van Boheemen S, Bestebroer TM, Osterhaus AD, Fouchier RA Isolation of a novel coronavirus from a man with pneumonia in Saudi Arabia. N Engl J Med. 2012;367(19):1814-20.

6. Bermingham A, Chand MA, Brown CS, Aarons E, Tong C, Langrish C, Hoschle K, Brown K, Galiano M, Myers R, et al. Severe respiratory illness caused by a novel coronavirus, in a patient transferred to the United Kingdom from the Middle East, September 2012. Euro Surveill. 2012;17(40):20290.

7. Albarrak AM, Stephens GM, Hewson R, Memish ZA. Recovery from severe novel coronavirus infection. Saudi Med J. 2012;33(12):1265-9.

8. Hsieh YH. 2015 Middle East Respiratory Syndrome Coronavirus (MERS-CoV) nosocomial outbreak in South Korea: insights from modeling. Peer J. 2015;3:e1505.

9. Health Protection Agency (HPA) UK Novel Coronavirus Investigation team. Evidence of person-to-person transmission within a family cluster of novel coronavirus infections, United Kingdom, February 2013. Euro Surveill. 2013;18(11):20427.

10. Assiri A, Abedi GR, Saeed AA, Abdalla MA, Al-Masry M, Choudhry AJ, Lu X, Erdman DD, Tatti K, Binder AM, et al. Multifacility Outbreak of Middle East Respiratory Syndrome in Taif. Saudi Arabia Emerg Infect Dis. 2016;22(1):32-40.

11. Alsahafi AJ, Cheng AC. The epidemiology of Middle East respiratory syndrome coronavirus in the Kingdom of Saudi Arabia, 2012-2015. Int J Infect Dis. 2016:45:1-4.

12. Drosten C, Seilmaier M, Corman VM, Hartmann W, Scheible G, Sack S, Guggemos W, Kallies R, Muth D, Junglen S, et al. Clinical features and virological analysis of a case of Middle East respiratory syndrome coronavirus infection. Lancet Infect Dis. 2013;13(9):745-51.

13. Memish ZA, Cotten M, Meyer B, Watson SJ, Alsahafi AJ, Al Rabeeah AA, Corman VM, Sieberg A, Makhdoom $\mathrm{HQ}$, Assiri A, et al. Human infection with MERS coronavirus after exposure to infected camels, Saudi Arabia, 2013. Emerg Infect Dis. 2014;20(6):1012-5.

14. Mackay IM, Arden KE. MERS coronavirus: diagnostics, epidemiology and transmission. Virol J. 2015;12:222.

15. Drosten C, Muth D, Corman VM, Hussain R, Al Masri M, HajOmar W, Landt O, Assiri A, Eckerle I, Al Shangiti A, et al. An observational, laboratory-based study of outbreaks of middle East respiratory syndrome coronavirus in Jeddah and Riyadh, kingdom of Saudi Arabia, 2014. Clin Infect Dis. 2015;60(3):369-77.

16. Sakamoto S, Tanaka H, Morimoto S. Towards the prophylactic and therapeutic use of human neutralizing monoclonal antibodies for Middle East respiratory syndrome coronavirus (MERS-CoV). Ann Transl Med. 2015:3(3):35

17. Zhou J, Chu H, Chan JF, Yuen KY. Middle East respiratory syndrome coronavirus infection: virus-host cell interactions and implications on pathogenesis. Virol J. 2015;12:218.

18. de Groot RJ, Baker SC, Baric RS, Brown CS, Drosten C, Enjuanes L, Fouchier RA, Galiano M, Gorbalenya AE, Memish ZA, et al. Middle East respiratory syndrome coronavirus (MERS-CoV): announcement of the Coronavirus Study Group. J Virol. 2013;87(14):7790-2.

19. Patino-Barbosa AM, Bedoya-Arias JE, Cardona-Ospina JA, Rodriguez-Morales AJ: Bibliometric assessment of the scientific production of literature regarding Mayaro. J Infect Public Health 2015.
20. Martinez-Pulgarin DF, Acevedo-Mendoza WF, Cardona-Ospina JA, Rodriguez-Morales AJ, Paniz-Mondolfi AE. A bibliometric analysis of global Zika research. Travel Med Infect Dis. 2016;14(1):55-7.

21. Cruz-Calderon S, Nasner-Posso KM, Alfaro-Toloza P, Paniz-Mondolfi AE, Rodriguez-Morales AJ. A bibliometric analysis of global Ebola research. Travel Med Infect Dis. 2015;13(2):202-4.

22. Zhao XY, Sheng L, Diao TX, Zhang Y, Wang L, Yanjun Z. Knowledge mapping analysis of Ebola research. Bratisl Lek Listy. 2015;116(12):729-34.

23. Bundschuh M, Groneberg DA, Klingelhoefer D, Gerber A. Yellow fever disease: density equalizing mapping and gender analysis of international research output. Parasit Vectors. 2013;6:331.

24. Vera-Polania F, Perilla-Gonzalez Y, Martinez-Pulgarin DF, Baquero-Rodriguez JD, Munoz-Urbano M, Lagos-Gallego M, Lagos-Grisales GJ, Villegas S, RodriguezMorales AJ. Bibliometric assessment of the Latin-American contributions in dengue. Recent Pat Antiinfect Drug Discov. 2014:9(3):195-201.

25. Munoz-Urbano M, Lopez-Isaza AF, Hurtado-Hurtado N, Gomez-Suta D, Murillo-Abadia J, Delgado-Osorio N, Lagos-Grisales GJ, Villegas S, MedinaMorales DA, Rodriguez-Morales AJ. Scientific research in malaria: bibliometric assessment of the Latin-American contributions. Recent Pat Antiinfect Drug Discov. 2014;9(3):209-15.

26. Perilla-Gonzalez Y, Gomez-Suta D, Delgado-Osorio N, Hurtado-Hurtado N, Baquero-Rodriguez JD, Lopez-Isaza AF, Lagos-Grisales GJ, Villegas S, Rodriguez-Morales AJ. Study of the scientific production on leishmaniasis in Latin America. Recent Pat Antiinfect Drug Discov. 2014;9(3):216-22.

27. Ramos JM, Gonzalez-Alcaide G, Bolanos-Pizarro M. Bibliometric analysis of leishmaniasis research in Medline (1945-2010). Parasit Vectors. 2013;6:55.

28. Fricke R, Uibel S, Klingelhoefer D, Groneberg DA. Influenza: a scientometric and density-equalizing analysis. BMC Infect Dis. 2013;13:454

29. Zheng HC, Yan L, Cui L, Guan YF, Takano Y. Mapping the history and current situation of research on John Cunningham virus - a bibliometric analysis. BMC Infect Dis. 2009:9:28.

30. Falagas ME, Pitsouni El, Malietzis GA, Pappas G. Comparison of PubMed, Scopus, Web of Science, and Google Scholar: strengths and weaknesses. Faseb J. 2008;22(2):338-42.

31. Scopus. Scopus: Content coverage guide. 2016; Available from: https:// www.elsevier.com/_data/assets/pdf_file/0007/69451/scopus_content_ coverage_guide.pdf. [Accessed 29 Apr 2016].

32. Zyoud SH, Al-Jabi SW, Sweileh WM. Worldwide research productivity of paracetamol (acetaminophen) poisoning: a bibliometric analysis (2003-2012). Hum Exp Toxicol. 2015;34(1):12-23.

33. Zyoud SH, Al-Jabi SW, Sweileh WM, Al-Khalil S, Alqub M, Awang R. Global methaemoglobinaemia research output (1940-2013): a bibliometric analysis. Springer Plus. 2015;4:626.

34. Zyoud SH, Al-Jabi SW, Sweileh WM, Awang R, Waring WS. Bibliometric profile of the global scientific research on methanol poisoning (1902-2012). J Occup Med Toxicol. 2015:10:17.

35. Zyoud SH, Al-Jabi SW, Sweileh WM, Awang R, Waring WS. Global research productivity of $\mathrm{N}$-acetylcysteine use in paracetamol overdose: A bibliometric analysis (1976-2012). Hum Exp Toxicol. 2015:34(10):1006-16.

36. Sweileh WM, Zyoud SH, Al-Jabi SW, Sawalha AF. Contribution of Arab countries to breast cancer research: comparison with non-Arab Middle Eastern countries. BMC Womens Health. 2015;15:25.

37. Zyoud SH. Bibliometric analysis on global Catha edulis (khat) research production during the period of 1952-2014. Global Health. 2015;11:39.

38. Hirsch JE. An index to quantify an individual's scientific research output. Proc Natl Acad Sci U S A. 2005;102(46):16569-72

39. Thomson Reuters. 2014 Journal Citation Reports ${ }^{\oplus}$. 2015; Available from: http://www.isiknowledge.com. [Accessed 13 Nov 2015]

40. Assiri A, McGeer A, Perl TM, Price CS, Al Rabeeah AA, Cummings DA, Alabdullatif ZN, Assad M, Almulhim A, Makhdoom H, et al. Hospital outbreak of Middle East respiratory syndrome coronavirus. N Engl J Med. 2013;369(5):407-16.

41. Reusken CB, Haagmans BL, Muller MA, Gutierrez C, Godeke GJ, Meyer B, Muth D, Raj VS, Smits-De Vries L, Corman VM. Middle East respiratory syndrome coronavirus neutralising serum antibodies in dromedary camels: a comparative serological study. Lancet Infect Dis. 2013;13(10):859-66.

42. Guery B, Poissy J, el Mansouf L, Sejourne C, Ettahar N, Lemaire X, Vuotto F, Goffard A, Behillil S, Enouf V, et al. Clinical features and viral diagnosis of two cases of infection with Middle East Respiratory Syndrome coronavirus: a report of nosocomial transmission. Lancet. 2013;381(9885):2265-72. 
43. Memish ZA, Mishra N, Olival KJ, Fagbo SF, Kapoor V, Epstein JH, Alhakeem R, Durosinloun A, Al Asmari M, Islam A, et al. Middle East respiratory syndrome coronavirus in bats. Saudi Arabia Emerg Infect Dis. 2013;19(11):1819-23.

44. Memish ZA, Zumla Al, Al-Hakeem RF, Al-Rabeeah AA, Stephens GM. Family cluster of Middle East respiratory syndrome coronavirus infections. N Engl J Med. 2013;368(26):2487-94.

45. van Boheemen S, de Graaf M, Lauber C, Bestebroer TM, Raj VS, Zaki AM, Osterhaus AD, Haagmans BL, Gorbalenya AE, Snijder EJ et al. Genomic characterization of a newly discovered coronavirus associated with acute respiratory distress syndrome in humans. MBio 2012, 3(6).

46. Raj VS, Mou H, Smits SL, Dekkers DH, Muller MA, Dijkman R, Muth D, Demmers JA, Zaki A, Fouchier RA, et al. Dipeptidyl peptidase 4 is a functional receptor for the emerging human coronavirus-EMC. Nature. 2013; 495(7440):251-4

47. Essential Science Indicators. Top 20 Countries in ALL FIELDS, 2001-August 31, 2011. 2012; Available from: http://archive.sciencewatch.com/dr/cou/ 2011/11decALL/. [Accessed 20 Sept 2013].

48. Khalid I, Khalid TJ, Qabajah MR, Barnard AG, Qushmaq IA. Healthcare Workers Emotions, Perceived Stressors and Coping Strategies During MERSCoV Outbreak. Clin Med Res. 2016;14(1):7-14.

49. Oboho IK, Tomczyk SM, Al-Asmari AM, Banjar AA, Al-Mugti H, Aloraini MS, Alkhaldi KZ, Almohammadi EL, Alraddadi BM, Gerber SI, et al. 2014 MERSCoV outbreak in Jeddah-a link to health care facilities. N Engl J Med. 2015;372(9):846-54.

50. Fagbo SF, Skakni L, Chu DK, Garbati MA, Joseph M, Peiris M, Hakawi AM. Molecular Epidemiology of Hospital Outbreak of Middle East Respiratory Syndrome, Riyadh, Saudi Arabia, 2014. Emerg Infect Dis. 2015;21(11):1981-8.

51. Majumder MS, Rivers C, Lofgren E, Fisman D: Estimation of MERS-Coronavirus Reproductive Number and Case Fatality Rate for the Spring 2014 Saudi Arabia Outbreak: Insights from Publicly Available Data. PLoS Curr 2014, 6.

52. Su S, Wong G, Liu Y, Gao GF, Li S, Bi Y. MERS in South Korea and China: a potential outbreak threat? Lancet. 2015;385(9985):2349-50.

53. Hui DS, Perlman S, Zumla A. Spread of MERS to South Korea and China. Lancet Respir Med. 2015;3(7):509-10.

54. Kim KM, Ki M, Cho SI, Sung M, Hong JK, Cheong HK, Kim JH, Lee SE, Lee C, Lee $\mathrm{K}$, et al. Epidemiologic features of the first MERS outbreak in Korea: focus on Pyeongtaek St. Mary's Hospital Epidemiol Health. 2015;37:e2015041.

55. Kim JS. Lessons learned from new emerging infectious disease. Middle East Respiratory Syndrome coronavirus outbreak in Korea. Epidemiol Health. 2015:37:e2015051.

56. Da Guan W, Mok CK, Chen ZL, Feng LQ, Li ZT, Huang JC, Ke CW, Deng X, Ling Y, Wu SG, et al. Characteristics of Traveler with Middle East Respiratory Syndrome, China, 2015. Emerg Infect Dis. 2015;21(12):2278-80.

57. Chen RC, Chu D, Chiang CH, Chou CT. Bibliometric analysis of ultrasound research trends over the period of 1991 to 2006. J Clin Ultrasound. 2009:37(6):319-23.

58. Kelly JC, Glynn RW, O'Briain DE, Felle P, McCabe JP. The 100 classic papers of orthopaedic surgery: a bibliometric analysis. J Bone Joint Surg (Br). 2010:92(10):1338-43.

59. Tas F. An analysis of the most-cited research papers on oncology: which journals have they been published in? Tumour Biol. 2014;35(5):4645-9.

60. Chen LM, Liu YQ, Shen JN, Peng YL, Xiong TY, Tong X, Du L, Zhang YG. The 100 top-cited tuberculosis research studies. Int J Tuberc Lung Dis. 2015;19(6):717-22.

61. Khan A, Choudhury N, Uddin S, Hossain L, Baur LA. Longitudinal trends in global obesity research and collaboration: a review using bibliometric metadata. Obes Rev. 2016;17(4):377-85.

62. Antoniou GA, Antoniou SA, Georgakarakos El, Sfyroeras GS, Georgiadis GS. Bibliometric analysis of factors predicting increased citations in the vascular and endovascular literature. Ann Vasc Surg. 2015;29(2):286-92.

63. Mostafavi E, Bazrafshan A. Research and collaboration overview of Institut Pasteur International Network: a bibliometric approach toward research funding decisions. Int J Health Policy Manag. 2014;2(1):21-8.

64. Du L, Jiang S. Middle East respiratory syndrome: current status and future prospects for vaccine development. Expert Opin Biol Ther. 2015:15(11):1647-51

65. Ma C, Li Y, Wang L, Zhao G, Tao X, Tseng CT, Zhou Y, Du L, Jiang S. Intranasal vaccination with recombinant receptor-binding domain of MERS$\mathrm{CoV}$ spike protein induces much stronger local mucosal immune responses than subcutaneous immunization: Implication for designing novel mucosal MERS vaccines. Vaccine. 2014;32(18):2100-8.

\section{Submit your next manuscript to BioMed Central and we will help you at every step:}

- We accept pre-submission inquiries

- Our selector tool helps you to find the most relevant journal

- We provide round the clock customer support

- Convenient online submission

- Thorough peer review

- Inclusion in PubMed and all major indexing services

- Maximum visibility for your research

Submit your manuscript at www.biomedcentral.com/submit
Biomed Central 